\title{
AKULTURASI ISLAM DAN NILAI LOKAL DALAM PERSPEKTIF PSIKOLOGI
}

\author{
Gazi Saloom \\ UIN Syarif Hidayatullah Jakarta \\ gazi@uinjkt.ac.id
}

\begin{abstract}
Abstrak
Akulturasi Islam dan nilai lokal adalah fakta sejarah sosial yang dapat disaksikan sampai saat ini. Keberagamaan dan spiritualitas menjadi ranah utama di mana terjadi akulturasi di antara keduanya.Psikologi terutama psikologi lingkungan dan budaya melihat bahwa manusia tidak bisa dilepaskan dari ikatan lokal atau ikatan tempat. Ikatan seseorang dengan tempat tertentu menimbulkan proses timbal balik secara pikiran, emosi dan tindakan. Proses pikiran, emosi dan tindakan itu membawa seseorang atau kelompok untuk mengaitkan keberagamaan dan ritual keagamaan dengan nilai-nilai lokal yang mewarnai kehidupan individu dan kelompok. Artikel ini hendak menegaskan bahwa akulturasi Islam dan nilai lokal adalah proses psiko-sosial-keagamaan yang bisa dijelaskan secara ilmiah dari perspektif psikologi.
\end{abstract}

\begin{abstract}
Acculturation between Islam and the local values is a sociohistorical fact that until now can be seen. Both Religiosity and spirituality become a primary domain for the acculturation between the two. Psychology, particularly the psychology of environment and culture, seeing that man can not be separated from the local or spatial bond. Individual ties with a particular
\end{abstract}


place raise a reciprocal process in thoughts, emotions and actions. This process in turn encourages individuals or groups to associate religiosity and religious rituals with local values characterizing their lives. This article asserts that Islamic acculturation and local value is the process of psycho-social-religious that can be described scientifically from the perspective of psychology

Key Word : Akulturasi, Islam, nilai, psikologi, lokal

\section{A. Pendahuluan}

Perkawinan Islam dan nilai lokal memiliki akar sejarah yang panjang dalam perjalanan misi keislaman para ulama di berbagai belahan dunia termasuk di Indonesia. Di tanah Jawa, strategi para ulama yang dikenal dengan sebutan Wali Songo dalam menyebarkan Islam didasarkan atas penghargaan terhadap nilai-nilai lokal yang terpelihara dengan baik pada masa itu. Sebut saja misalnya bagaimana Sunan Kudus tetap menghargai keyakinan umat Hindu pada masa itu yang menempatkan sapi sebagai hewan suci yang tidak boleh diganggu apalagi dikonsumsi. Jejak sejarah itu masih bisa ditemukan pada masyarakat Muslim Jawa yang tinggal di sekitar daerah Kudus dan sekitarnya di mana sajian kuliner yang berasal dari daging sapi tidak ada sama sekali. Sebagai gantinya, masyarakat Kudus dansekitarnya membuat bahan kuliner dari daging kerbau seperti sate kerbau atau gulai kerbau. ${ }^{1}$

Penghargaan terhadap nilai lokal tidak hanya meliputi bidang kuliner tetapi juga bidang ritual keagamaan atau kegiatan keagamaan yang melibatkan masyarakat Muslim dalam skala yang luas. Hal itu misalnya dapat ditemukan dalam ritual sekaten di Yogyakarta, ritual Wetu Telu di Lombok dan ritual lainnya di berbagai daerah di Indonesia. Semua itu mencerminkan betapa Islam adalah agama yang elastis dan

${ }^{1}$ Wawancara dan observasi dengan pedagang di Kota Kudus pertengahan tahun 2014 
adaptif dengan nilai-nilai setempat. Mengapa perkawinan Islam dengan nilai lokal terjadi?

Dilihat dari perspektif psikologi, integrasi Islam dengan nilai lokal sangat mungkin terjadi. Sebab, psikologi memandang, setidaknya yang dianut sebagai besar ilmuwan psikologi, bahwa teks termasuk teks-teks suci keagamaan tidak memberikan makna dengan sendirinya tetapi manusia sebagai subyek adalah faktor penting yang memberikan makna terhadap segala hal yang berkaitan dengan kitab suci atau sumber rujukan keagamaan yang otoritatif. Tentang hal itu, para ilmuwan psikologi penganut aliran kognitif mempopulerkan adagium yang berbunyi, "words dont mean but people mean" untuk menegaskan bahwa manusia dan perilakunya merupakan faktor penting yang memberi warna terhadap semua simbol dan narasi termasuk yang terkait dengan agama. ${ }^{2}$

Terdapat banyak studi tentang Islam dan nilai lokal, misalnya penelitian Heryati dan Nurnaningsih Nico Abdul (2014) yang meneliti tentang kearifan lokal pada arsitektur Vernakular Gorontalo: Tinjauan pada aspek budaya dan nilainilai Islam. Ada juga studi lain, misalnya Asnawan (2011) yang menulis tentang Islam dan akulturasi budaya lokal di Indonesia dan telah dimuat di Jurnal Falasifa Volume 2 Nomor 2 September 2011. Asnawan melihat perkawinan Islam dan nilai lokal dalam perspektif ilmu syariah dengan menggunakan konsep al-Urf dan al-Mashlahah al-Mursalah sebagai dasar analisis. Namun, dari sekian banyak penelitian tidak banyak - untuk tidak mengatakan tidak ada satupun - yang melihat proses perkawinan Islam dan nilai lokal dari sudut pandang psikologi. Perspektif psikologi terutama

${ }^{2}$ Baumeister, Roy F. "Social psychologists and thinking about people", dalam Advanced social psychology : the state of the science, by Roy F. Baumeister and Eli J. Finkel, (New York: Oxford University Press, Inc., 2010), h. 5-24. 
psikologi sosial, psikologi lingkungan, psikologi budaya dan psikologi agama diperlukan untuk memberikan pengayaan terhadapat pemahaman komprehensif tentang isu Islam dan nilai lokal.Tulisan ini salah satunya ditujukan untuk mengisi ruang kosong itu.

Pentingnya paradigma psikologi digunakan dalam hal ini karena interaksi antara Islam dan nilai lokal tidak bisa dilepaskan dari cara manusia memahami, merasakan dan memperlakukan Islam dan nilai lokal sebagai dua kesatuan yang tidak bisa dipisahkan. Selain itu, melihat hubungan Islam dan nilai lokal dari sudut pandang psikologi adalah hal unik yang berbeda dengan sudut pandang lain yang umumnya digunakan seperti filsafat, sosiologi atau ilmu syariah.

\section{B. Keberagamaan dalam Islam}

Keberagamaan dan spiritualitas telah menjadi bagian penting dari pengalaman manusia sepanjang sejarah peradaban dan perkembangan kebudayaan manusia. Semua orang dari berbagai kalangan, kategori dan kelas adalah pelaku atau obyek dalam berbagai bidang kegiatan manusia seperti seni, musik, budaya, perang, moral, konflik dan kegiatan lainnya. Semua kegiatan itu memberikan pengalaman yang sarat dengan keberagamaan dan spiritualitas. ${ }^{3}$ Dengan demikian, keberagamaan dan spiritualitas dapat ditemukan pada setiap aktivitas yang kita lakukan sehari-hari.

Dalam pandangan sejumlah ahli seperti Bellah dan James yang mewakili kaum sosiolog dan psikolog, ditekankan kata kunci simbol dan ketuhanan sebagai konsep yang menjelaskan makna beragama. Bellah (1970) menyebutkan bahwa keberagamaan adalah serangkaian bentuk dan

${ }^{3}$ Zinnbauer, Brian J., and Kenneth I. Pargament, "Religiousness and Spirituality." Dalam Raymond F. Paloutzian and Crystal L. Park, Handbook of the psychology of religion and spirituality, (New York: The Guilford Press, 2005), h. 23 
tindakan simbolik yang menghubungkan manusia dengan kondisi puncak dari eksistensi seseorang. Sedangkan James (1920) menyebutkan keberagamaan sebagai perasaan, tindakan dan pengalaman manusia dalam kesendirian sejauh mereka memahami diri mereka untuk menegakkan hubungan dengan apa yang dianggap bersifat ketuhanan. ${ }^{4}$

Islam sebagai agama yang menekankan hubungan dua arah, vertikal dan horizontal, memberikan penegasan bahwa ibadah adalah penerapan dari pemahaman tentang bagaimana umat Islam berinteraksi dengan Sang Pencipta dan bagaimana berinteraksi dengan lingkungan sosial dan lingkungan alam. Proses interaksi yang melibatkan manusia sebagai pelaku utama dalam beribadah di satu sisi, serta Tuhan, lingkungan sosial dan alam di sisi lain memberikan pemahaman bahwa manusia tidak bisa membebaskan diri dari nilai ketuhanan dan nilai lingkungan (lokal, tempat).

Pada titik ini, pertemuan antara Islam sebagai nilai yang berasal dari Tuhan dan nilai lokal dapat dilihat sebagai perwujudan dan hasil dari interaksi manusia dengan lingkungan setempat yang menghasilkan perilaku atau aktivitas termasuk yang bersifat keagamaan atau keislaman. Ritual-ritual ibadah terutama yang menyangkut muamalah ma'a al-nas (interaksi seseorang atau masyarakat Muslim dengan lingkungan sosial maupun lingkungan alam) tidak luput dari bagaimana manusia memperlakukan orang lain atau lingkungan dalam kehidupan sehari-hari.

Bagaimana memperlakukan orang lain dan lingkungan atau dalam bahasa lain pola interaksi antara manusia dengan manusia dan manusia dengan lingkungan sangat dipengaruhi oleh nilai-nilai dan hasil kombinasi antara Islam dengan budaya dan kearifan lokal. Itulah yang menjelaskan mengapa

${ }^{4}$ Ibid., 
ekspresi dan ritual keagamaan mencerminkan integrasi nilai dan ajaran Islam dengan nilai lokal.

Integrasi tersebut dimungkinkan terjadi bila kita merujuk kepada konsep al-urf dan al-maslahah al-mursalah dalam kaidah ushul fikih. Pengakuan dan penggunaan kedua konsep tersebut oleh para ulama manunjukkan bahwa tradisi dan kemaslahatan menjadi sumber pertimbangan dasar dalam menentukan hukum. Hal itu menjadi argumen lain yang menguatkan bahwa nilai lokal mendapatkan kedudukan yang terhormat dalam kehidupan keagamaan umat Islam.

Prof. Dr Nurcholis Madjid menjelaskan bahwa alQuran dan Hadis Nabi sangat mengakomodir nilai-nilai lokal. Misalnya ia berargumen bahwa penyebutan kata "al-ma'ruf" sebagai yang seakar dengan al-urf mengandung pengertian nilai-nilai kebajikan atau tradisi baik yang dikenal banyak orang. Jadi, kebajikan dan keberagamaan adalah sesuatu yang mengandung nilai kebaikan yang diketahui dan diakui oleh banyak orang. Dengan kata lain, kebajikan dan keberagamaan adalah nilai yang bersifat konstruktif secara sosial-budaya ${ }^{5}$.

Jika seseorang melakukan kebaikan tetapi masyarakat di sekitarnya tidak menganggapnya sebagai suatu kebaikan maka nilai kebaikan itu dipertanyakan karena kebaikan akan bernilai ketika orang lain atau masyarakat mendapatkan keuntungan dari kebaikan itu. Tidak ada kebaikan yang lahir dari ruang vacuum atau tidak ada kebaikan yang bernilai kebaikan sejati jika nilainya hanya dapat dimanfaat oleh seseorang secara individual tanpa melibatkan banyak orang dan proses budaya.

Dalam ungkapan yang lain, saya berpikir bahwa jika anda seorang yang saleh maka kesalehan anda hanya bermanfaat untuk kebaikan anda sendiri bukan untuk kebaikan orang banyak. Sebaliknya jika anda seorang musleh maka kesalehan yang lakukan bukan hanya bermanfaat untuk

${ }^{5}$ Nurcholish, Madjid, "Menjawab: Menatap Islam Masa Depan” dalam Ulumul Qur'an, No.1, Vol.V, Th. 1994, h. 54. 
anda sendiri tetapi juga untuk orang banyak. Bahkan, dalam hal ini kebaikan yang diwujudkan oleh seorang muslih kerapkali lebih banyak bermanfaat untuk orang banyak dibandingkan dirinya sendiri.

Dalam bahasa yang lebih tegas, dalam pandangan Islam setidaknya yang saya yakini bahwa kesalehan sosial lebih utama dibandingkan kesalehan personal jika harus dibandingkan di antara keduanya. Tentu dengan tetap diingat atau dicatat bahwa kesalehan sosial bermula dari kesalehan personal atau dengan kata lain, untuk menjadi seorang muslih maka anda harus menjadi seorang yang saleh terlebih dahulu. Gambaran hubungan saleh dengan muslih serta hubungan kesalehan personal dengan kesalehan sosial dapat digambarkan sebagaimana skema di bawah ini.

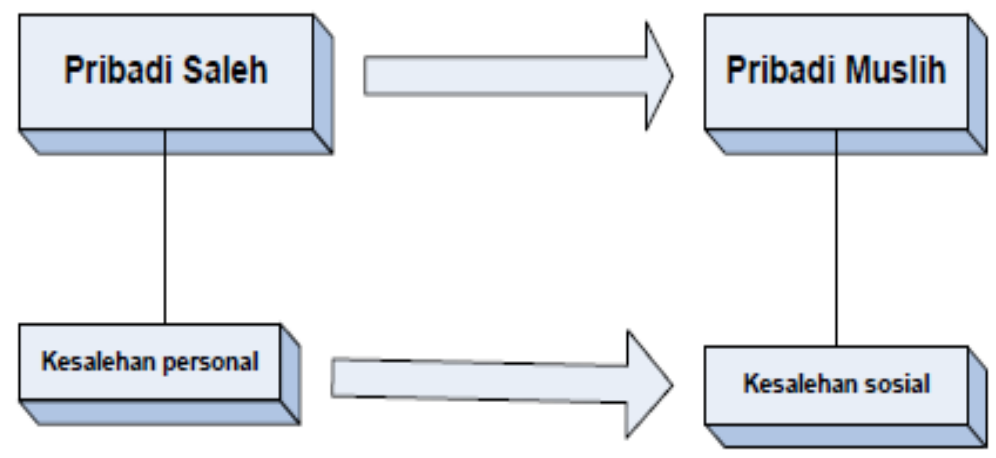

Gb. 1

\section{Nilai dan Identitas Lokal}

Nilai lokal yang umumnya bersumber dari warisan budaya setempat kerapkali menjadi bagian tak terpisahkan dari ajaran agama. Hal itu misalnya terlihat pada masyarakat Hindu Bali di mana sulit dibedakan antara anasir agama dan budaya. Agama dan budaya seolah-olah satu kesatuan yang tidak mungkin dipilah satu sama lain sehingga banyak orang berpendapat bahwa agama adalah bagian dari budaya. 
Dalam kajian ilmu perilaku terutama psikologi sosial dan psikologi lingkungan, tempat atau lokal merupakan pusat makna atau medan kepedulian yang didasarkan atas pengalaman manusia, hubungan sosial, emosi dan pikiran. Dengan demikian, bisa dikatakan bahwa tempat atau lokal di mana manusia hidup adalah reservoir makna di mana manusia dapat mengambil ragam makna dan tafsir yang kemudian diimplementasikan dalam perilaku dan kehidupan seharihari termasuk perilaku dalam kehidupan keagamaan. Dengan demikian, secara psikologis, hubungan antara manusia dan tempat di mana mereka menetap sangat kuat karena dari sanalah lahir makna dan kebermaknaan. ${ }^{6}$

Lokal bukan sekadar lanskap tetapi lokus di mana terjadi proses pemaknaan oleh manusia dalam kaitan dengan berbagai kegiatan yang dilakukan sehari-hari. Dalam hal ini, ada tiga komponen kesadaran tempat yang bisa menjelaskan bagaimana lokal menjadi sumber nilai termasuk dalam beragama atau dalam berislam, yaitu lokal sebagai seting fisik, lokal sebagai seting kegiatan manusia serta lokal sebagai tempat terjadinya proses sosial dan psikologis manusia.

Proses sosial dan psikologis yang berlangsung dalam kesadaran manusia melibatkan tiga anasir yaitu lokal, kegiatan dan interaksi manusia. Dalam perspektif psikologi pada umumnya, proses sosial dan psikologis selalu bersandar pada tiga hal yaitu proses kognitif yang melibatkan alam pikiran, proses afektif yang melibatkan alam perasaan dan proses psikomotorik yang melibatkan aktivitas motorik. Ketiga proses itu jalin-menjalin dalam waktu yang lama sehingga melahirkan ikatan yang kuat antara seseorang dengan lokasi dan kegiatan yang dilakukan setiap hari. Itulah yang meneguhkan kesadaran lokal atau tempat dalam kehidupan manusia.

${ }^{6}$ Richard C. Stedman, “Toward social psychology of place: Predicting behavior from place-based cognitions, attitude, and identity, dalam jurnal "Environment and Behavior, Vol. 34 No. 5, September, 2002, h. 561-581. 
Penelitian tentang kesadaran lokal telah banyak dilakukan ahli sehingga melahirkan banyak teori tentang hal itu. Secara umum, teori dan penelitian tentang kesadaran tempat dapat dibagi menjadi dua pendekatan utama yaitu pendekatan positivistik dan pendekatan fenomenologis. Dari keduanya, tradisi yang kedua yaitu pendekatan fenomenologis yang sangat menekankan karakter patrikularistik tempat terkati individu, kelompok dan situasi cenderung lebih dominan dibandingkan tradisi pertama dalam hal ini pendekatan positivistik.

Para ahli teori tentang ruang dan lokal seperti Tuan dan Edward Relph kerapkali mengidentifikasi diri mereka sebagai kelompok ahli yang berafiliasi kepada pendekatan fenomenologis dan selalu melakukan pengujian hipotesis formal dalam kegiatan penelitian mereka tentang tempat. Kendati demikian, kedua ahli ini membuat pernyataan yang kuat tentang kesadaran tempat berdasarkan misalnya jangka waktu pengalaman atau kedalaman pengalaman dengan tempat, mobilitas sosial yang memungkinkan setiap orang melakuan abstraksi untuk mengembangkan suatu kesadaran tentang tempat atau hubungan sosial yang terjadi dalam suatu tempat sebagai dasar ikatan dibandingkan landscape itu sendiri. Hal itu menggambarkan suatu pandangan bahwa lokal atau tempat harus diperlakukan secara holistik karena memperlakukan tempat sebagai sesuatu yang terkait hubungan sebab-akibat dapat merusak esensi keseluruhan konsep.

Sebaliknya, pendekatan positivistik tentang kesadaran lokal dicirikan dengan metode kuantitatif dan pengujian hipotesis tradisional. Pendekatan positivistik kerapkali mengabaikan ajaran teoritis yang penting tentang lokal termasuk hubungan antara makna simbolik dengan bagaimana kita mengevaluasi lokal, kedudukan lokal sebagai modal alamiah dan dampak kesadaran tempat terhadap perilaku. 


\section{Model Psikologis Keberagamaan}

Teks-teks psikologi yang paling klasik sampai yang paling mutakhir menyebutkan bahwa perilaku manusia dapat dijelaskan oleh dua faktor utama, yaitu faktor kepribadian dan faktor lingkungan. Faktor kepribadian berkaitan dengan halhal yang terkonstruksi di dalam diri setiap orang seperti cara berpikir, keyakinan, ideologi dan lain-lain, sedangkan faktor lingkungan berkaitan dengan hal-hal yang berada di luar diri seseorang seperti tempat dan nilai lokal yang dipegang teguh masyarakat.

Kurt Lewin, misalnya, seorang psikolog yang mengembangkan Teori Medan Perilaku menjelaskan bahwa perilaku manusia adalah fungsi dari interaksi antara pribadi manusia dan lingkungan. Dengan kata lain, perilaku manusia menggambarkan proses silang antara nilai-nilai dan keyakinan pribadi manusia dengan faktor lingkungan di mana seseorang menetap dalam waktu yang lama. Kurt Lewin membuat rumusan matematis untuk menjelaskan bagaimana faktor internal manusia yang berinteraksi dengan faktor eksternal lingkungan membentuk perilaku atau aktivitas manusia. Rumus matematis Kurt Lewin tentang perilaku manusia cukup sederhana, yaitu : $B=f(P+E)$. Simbol $B$ adalah representasi dari perilaku, $\mathrm{P}$ berarti personal dan E berarti lingkungan ${ }^{7}$.

Beragama atau berislam adalah gambaran dari perilaku yang mencerminkan aspek kepribadian yang tidak lain adalah reservoir berbagai nilai, filosofi dan ajaran normatif yang bersumber di antaranya dari agama dan budaya di satu sisi, dan di sisi lain mencerminkan pengaruh eksternal lingkungan fisik dan sosial yang melingkupi manusia.

${ }^{7}$ Roy F. Baumeister, "Social psychologists and thinking about people", Dalam Advanced social psychology : the state of the science, by Roy F. Baumeister and Eli J. Finkel, (New York: Oxford University Press. Inc, 2010), h. 5-24. 
Dalam tradisi psikologi behavioristik, suatu aliran yang menekankan faktor kebiasaan dan pembiasaan, disebutkan bahwa kebiasaan terjadi karena proses pembiasaan atau conditioning yang dilakukan secara konsisten. Dengan merujuk kepada prinsip dasar ini maka bisa dikatakan bahwa beragama atau berislam dengan mengkombinasikan nilai lokal dengan Islam berlangsung melalui kebiasaan yang dibiasakan sejak lama. Pertanyaan selanjutnya adalah bagaimana praktek Islam yang berbasis nilai lokal bisa menjadi praktek kolektif yang berlangsung secara turun-temurun?

Teori belajar sosial yang digagas Albert Bandura bisa menjelaskan hal itu. Prinsip dasar teori belajar sosial menekankan bahwa manusia bisa belajar untuk melakukan sesuatu melalui pengamatan terhadap apa yang dilakukan orang lain dan hasil yang muncul dari semua yang dilakukan banyak orang. Dalam hal ini, kognisi atau pikiran memainkan peran penting dalam proses belajar atau pembiasaan diri. Kesadaran atau harapan untuk mendapatkan ganjaran atau feedback positif di masa depan terutama dari Tuhan dan lingkungan sosial menjadi alasan krusial mengapa perilaku tertentu, dalam hal ini, ritual keagamaan yang memadukan Islam dan nilai lokal dilakoni oleh komunitas tertentu dalam Islam. Teori belajar sosial ini dianggap oleh para ahli psikologi sosial sebagai teori transisi yang menjadi titian menuju teori kognisi sosial. Dalam konteks menjelaskan Islam dan nilai lokal, teori kognisi sosial hemat penulis lebih komprehensif dalam menggambarkan bagaimana proses sosial dan psikologis menghasilkan kecenderungan memadukan berbagai nilai di dalam dirinya dan kelompoknya. Menurut teori kognisi sosial, perilaku manusia dapat dijelaskan oleh tiga faktor utama yaitu: Pertama, faktor personal atau faktor pikiran yang melekat pada setiap orang seperti pengetahuan, harapan dan sikap. Kedua, faktor lingkungan seperti norma sosial, akses di masyarakat dan pengaruh pada orang lain. Ketiga, faktor 
yang bersifat tingkah laku seperti keahlian, kecenderungan menerapkan nilai yang dianut pribadi dan kelompok, serta self-efficacy atau keyakinan bahwa seseorang atau kelompoknya bisa melakukan apa saja yang diinginkan ${ }^{8}$.

Ketiga faktor yang menentukan perilaku manusia digambarkan dalam bentuk segitiga yang saling berhubungan atau saling mempengaruhi satu sama lain. Hubungan antara ketiga faktor dijelaskan sebagaimana gambar berikut ini:

Faktor Lingkungan

- Norma sosial

- Akses di Masyarakat

- Pengaruh terhadap orang lain (kemampuan mengubah lingkungan sendiri
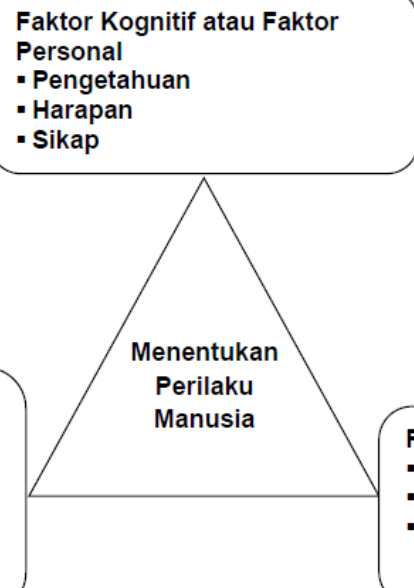

Faktor Behavioral

- Keahlian

- Praktek

Keyakinan akan kemampuan diri

Gb. 2. Hubungan Faktor Yang Mempengaruhi Perilaku Manusia

Terdapat banyak konsep yang menjelaskan tentang hubungan antara manusia dan seting ruang, tetapi sense of place (SOP) atau kesadaran lokal merupakan konsep yang paling terkenal dan banyak digunakan dalam kajian psikologi terutama psikologi sosial dan psikologi lingkungan. Kesadaran lokal merujuk kepada suatu konsep menyeluruh yang meliputi beberapa konsep lainnya yang menggambarkan hubungan manusia dengan seting ruang. Secara umum, kesadaran lokal adalah makna yang dikaitkan dengan seting ruang oleh individu atau kelompok.

${ }^{8}$ Ibid., h. 25-30. 
Tuan (1979) memberikan definisi yang paling tepat tentang kesadaran lokal, yaitu suatu pusat pemaknaan atau bidang kepedulian yang menekankan emosi dan hubungan manusia. Selanjutnya Ryden (1993) menambahkan bahwa suatu lokal -lebih dari sekadar suatu titik dalam ruang tetapi merupakan makna yang diperoleh manusia dari pemandangan melalui proses penghayatan terhadapnya. Dengan demikian, kesadaran lokal tidak saja berkaitan dengan seting fisik tetapi berkaitan dengan penafsiran manusia tentang seting tempat. ${ }^{9}$

Kesadaran tempat memiliki tiga dimensi yaitu ikatan lokal, identitas lokal dan ketergantungan lokal. Walaupun terkesan ketiga dimensi kesadaran lokal ini tumpang tindih tetapi tentu saja ada distingsi masing-masing dimensi yang dapat membedakannya dengan dimensi yang lain.

Identitas tempat adalah dimensi-dimensi diri yang menggambarkan identitas personal secara individual dalam hubungannya dengan lingkungan fisik melalui pola gagasan, keyakinan, preferensi, perasaan, nilai, tujuan dan kecenderungan berperilaku serta keahlian yang relevan dengan lingkungan. Sebagai suatu struktur kognitif, identitas tempat merupakan sub-struktur dari identifikasi diri yang lebih global sebagaimana kita memahami identitas jender dan identitas peran.

Sementara ikatan tempat digambarkan sebagai suatu ikatan positif yang berkembang antara kelompok atau individu dengan lingkungan. Secara tersurat, ikatan tempat terdiri dari hal-hal yang bersifat emosional. Misalnya, Riley (1992) menekankan ikatan tempat sebagai suatu hubungan afektif antara manusia dengan landskap berlangsung melalui proses berpikir, preferensi dan penilaian, sementara ahli lain seperti Altman dan Low (1992) menyebutkan bahwa ikatan lokal meliputi hubungan afeksi dengan emosi, pengetahuan

${ }^{9}$ Richard C. Stedman, “Toward Social, h. 561-581 
dan keyakinan, serta perilaku dan tindakan dengan merujuk kepada suatu tempat.

Selanjutnya, ketergantungan tempat didefinisikan sebagai kekuatan hubungan antara diri seseorang dengan tempat-tempat tertentu yang dipersepsikan seseorang. Kekuatan hubungan ini tidak selalu positif berdasarkan tingkat perbandingan atau model alternatif tingkat perbandingan dari Thibaut dan Kelly (1959) tetapi bisa juga negatif. Jika hubungan seseorang dengan suatu tempat kuat dan positif maka kesadaran tempat pada orang itu juga kuat sehingga pada gilirannya akan melahirkan ikatan yang kuat di antaranya keduanya, lalu muncul pula kondisi ketergantungan secara psikologis dan sosial terhadap lingkungan, dan terakhir menciptakan identitas tempat ${ }^{10}$.

Dalam kajian psikologi lingkungan, terutama terkait kesadaran lokal atau tempat, isu-isu keagamaan biasanya dijelaskan dalam konteks hubungan antara ikatan tempat dengan manusia atau person, tempat dan proses psikologis. Jika digambarkan dalam bentuk skema maka dapat dilihat dalam bentuk seperti ini. 


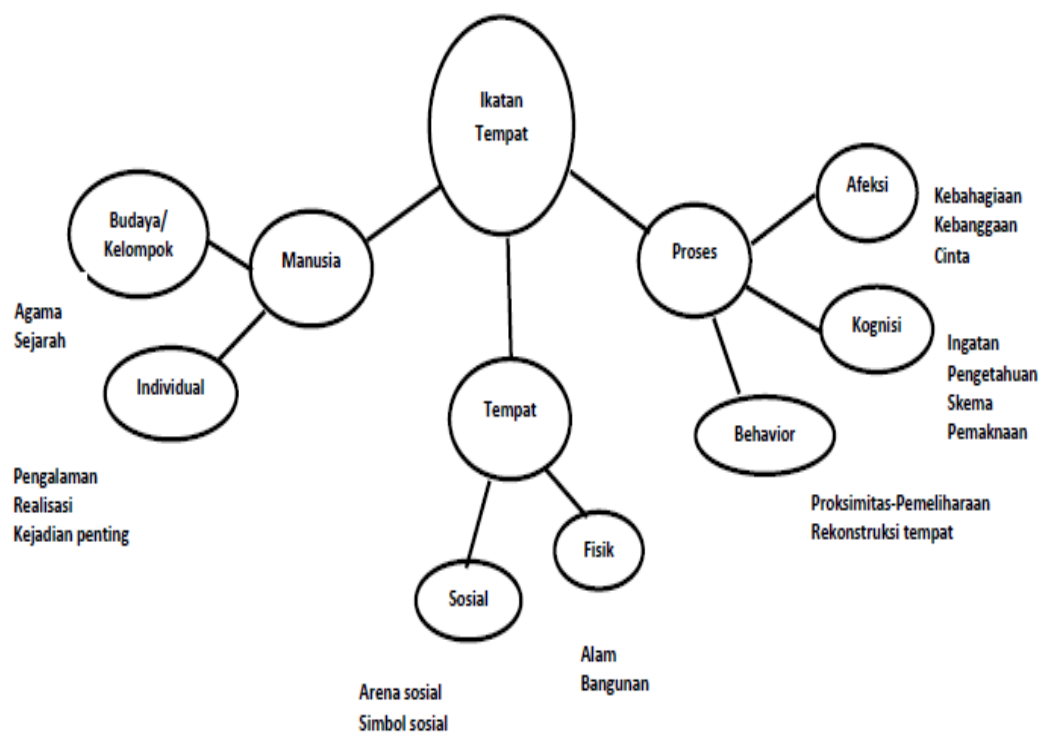

Gb. 3. Hubungan Ikatan Tempat dengan Manusia

Jika merujuk kepada skema di atas maka ikatan lokal sangat erat kaitannya dengan manusia sebagai subyek yang aktif dalam memproses pikiran, perasaan dan tindakan. Proses tersebut berlangsung secara individual atau secara kelompok atau secara kultural dalam konteks lingkungan sosial maupun lingkungan alam. Dalam hal ini, agama atau keberagamaan adalah bagian penting dalam rangkaian proses terjadinya ikatan antara manusia dan tempat sehingga muncul berbagai bentuk ritual keagamaan atau karya keagamaan yang menggambarkan akulturasi antara agama dan nilai lokal.

Contoh kongkrit yang bisa menjelaskan hal itu adalah Masjid Demak di Jawa Tengah. Bentuk masjid terutama pada ranggon atau atap yang berlapis pada masa itu diambil dari konsep "Meru" dari masa Hindu-Budha yang terdiri dari sembilan susun. Sunan Kalijaga, salah satu dai dan ulama Wali Songo memotongnya menjadi tiga potong yang menggambarkan konsep iman, Islam dan ihsan. 


\section{E. Penutup}

Berdasarkan uraian penulis sebelumnya tentang Islam dan nilai lokal dalam persepktif psikologi sebelumnya maka dapat disimpulkan bahwa akulturasi Islam dan nilai lokal atau integrasi Islam dan budaya lokal adalah proses sosial dan psikologis yang tidak bisa dihindarkan oleh siapapun. Hal itu karena manusia termasuk umat Islam memiliki ikatan yang kuat dengan lokal atau tempat tertentu sehingga turut mempengaruhi bagaimana pemahaman dan praktek Islam terbentuk.

Dengan kata lain, Islam yang dipraktekkan dengan sentuhan nilai lokal atau budaya setempat adalah Islam yang telah menyejarah dan membudaya sebagai hasil perenungan dan penghayatan manusia terhadap makna dan nilai lokal melalui proses psiko-sosial yang panjang. [.] 


\section{DAFTAR PUSTAKA}

Baumeister, Roy F., "Social psychologists and thinking about people ." In Advanced social psychology : the state of the science, by Roy F. Baumeister and Eli J. Finkel, 5-24. New York: Oxford University Press, Inc, 2010.

Borden, Kenneth S., and Irwin A. Horowitz, Social Psychology: Second Edition. Mahwah New Jersey: Lawrence Erlbaum Associates, 2002.

Heryati, and Nurnaningsih Nico Abdul. "Kearifan Lokal Pada Arsitektur Vernakular Gorontal: Tinjauan Pada Aspek Budaya dan Nilai-nilai Islam”, dalam el Harakah, Vol. 16 No. 2, Thaun 2014.

Inglehart, Ronald, and Norris, Pippa, Muslim Integration into Western Cultures: Between Origins and Destination. Faculty Research Working Papers Series, Harvard: Harvard Kennedy School, 2009.

Ishomuddin, Vina Salviana DS, Tonny Dian Effendy, Norio Suzuki, and Aiko Kashimura. "The Struggle of Islam and Local Values in Japan.” Konfrensi Nasional Ke-2 Asosiasi Program Pascasarjana Perguruan Tinggi Muhammadiyah (АРPРTM). Yogyakarta: Konfrensi Nasional Ke-2 Asosiasi Program Pascasarjana Perguruan Tinggi Muhammadiyah (APPPTM), 2015.

Reis, Harry T., "How we get here from there: A brief history of social psychology." In Advanced social psychology : the state of the science, by Roy F. Baumeister and Eli J. Finkel, 25-35. New York: Oxford University Press, 2015.

Said, Muhazzab, "Kajian Akulturasi Islam dan Budaya Lokal: Bungamale Sebagai Budaya Lokal Sulawesi Selatan.” AlFikr. Volume 16 Nomor 3, Tahun 2012. 
Scannel, Leila, and Robert Gifford, "Defining place attachment: A tripartite organizing framework." Journal of Environmental Psychology 30, 2010.

Seager, Paul. Social Psychology: A Complete Introduction, London: Hodder \& Stoughton, 2014.

Stedman, Richard C., "Toward social psychology of place: Predicting behavior from place-based cognitions, attitude, and identity." Environment and Behavior, Vol. 34 No. 5, September Tahun 2002.

Zinnbauer, Brian J., and Kenneth I. Pargament, "Religiousness and Spirituality." In Handbook of the psychology of religion and spirituality, by Raymond F. Paloutzian and Crystal L. Park, 123-143. New York: The Guilford Press, 2005. 